\title{
Contemporary Nutrition Strategies to Optimize Performance in Distance Runners and Race Walkers
}

\author{
Louise M. Burke \\ Australian Institute of Sport and Australian Catholic University
}

\author{
Asker E. Jeukendrup \\ Loughborough University \\ Martin Mooses \\ University of Tartu
}

\begin{abstract}
Distance events in Athletics include cross country, 10,000-m track race, half-marathon and marathon road races, and 20- and 50-km race walking events over different terrain and environmental conditions. Race times for elite performers span $\sim 26$ min to $>4 \mathrm{hr}$, with key factors for success being a high aerobic power, the ability to exercise at a large fraction of this power, and high running/walking economy. Nutrition-related contributors include body mass and anthropometry, capacity to use fuels, particularly carbohydrate (CHO) to produce adenosine triphosphate economically over the duration of the event, and maintenance of reasonable hydration status in the face of sweat losses induced by exercise intensity and the environment. Race nutrition strategies include CHO-rich eating in the hours per days prior to the event to store glycogen in amounts sufficient for event fuel needs, and in some cases, in-race consumption of $\mathrm{CHO}$ and fluid to offset event losses. Beneficial $\mathrm{CHO}$ intakes range from small amounts, including mouth rinsing, in the case of shorter events to high rates of intake $(75-90 \mathrm{~g} / \mathrm{hr})$ in the longest races. A personalized and practiced race nutrition plan should balance the benefits of fluid and $\mathrm{CHO}$ consumed within practical opportunities, against the time, cost, and risk of gut discomfort. In hot environments, prerace hyperhydration or cooling strategies may provide a small but useful offset to the accrued thermal challenge and fluid deficit. Sports foods (drinks, gels, etc.) may assist in meeting training/race nutrition plans, with caffeine, and, perhaps nitrate being used as evidence-based performance supplements.
\end{abstract}

Keywords: African runners, $\mathrm{CHO}$ loading, $\mathrm{CHO}$ periodization, marathon, track and field

The International Association of Athletics Federations recognizes various distance events, with current World Championship and Olympic Games hosting the 10,000-m track event and road marathon $(42.2 \mathrm{~km})$ in running and 20 and $50-\mathrm{km}$ events in race walking. In addition, there are separate International Association of Athletics Federations Road Race Label events spread throughout the year in half marathons, marathons, and other distance races, a half-marathon World Championship, cross-country World Championships $(10 \mathrm{~km})$, and various Race Walking Cups and Challenges. Many events are held as national or continental titles and include competitions for junior athletes (e.g., under 20 or under 18 years) over shorter distances.

Table 1 summarizes the characteristics of key distance running and race walking events, noting the duration and intensity of races for top competitors and elements that contribute to the physiological and nutrition challenges of these events. Meanwhile, opportunities to address these challenges via within-event nutrition strategies are summarized in Table 2. As in middle-distance events, there are tactical, technical, and physiological components to successful

Burke is with the Australian Institute of Sport, Belconnen, ACT, Australia; and the Mary MacKillop Institute for Health Research, Australian Catholic University, Melbourne, VIC, Australia. Jeukendrup is with the School of Sport, Exercise and Health Sciences, Loughborough University, Loughborough, United Kingdom. Jones is with the Department of Sport and Health Sciences, University of Exeter, Exeter, United Kingdom. Mooses is with the Institute of Sport Sciences and Physiotherapy, University of Tartu, Tartu, Estonia. Burke (Louise.burke@ ausport.gov.au) is corresponding author. outcomes. This paper focuses on knowledge that has emerged over the past decade on nutrition strategies to support the training and competition goals of distance runners and race walkers, translating race nutrition principles into practical recommendations.

\section{Bioenergetic and Physiological Determinants of Success in Distance Events}

The distance events (from $\sim 26$ min in the 10,000-m track race to $>3.5 \mathrm{hr}$ in the 50-km race walk) are considered "submaximal," with mean energy requirements of $\sim 75-92 \%$ of maximal oxygen uptake ( $\dot{\mathrm{VO}}_{2}$ max; Londeree, 1986). These are heavily dependent on aerobic resynthesis of adenosine triphosphate (Coyle, 2007) and require adequate delivery of $\mathrm{O}_{2}$ from the atmosphere to the mitochondria to oxidize carbohydrate ( $\mathrm{CHO}$ ) and lipid fuels. When energy contribution from anaerobic metabolism is minimal, the performance is typically related to three key factors (Joyner \& Coyle, 2008): $\dot{\mathrm{VO}}_{2} \max$, the fraction of $\dot{\mathrm{VO}}_{2} \max$ that can be sustained for the distance, and running/walking economy. For example, a $\dot{\mathrm{V}} \mathrm{O}_{2} \mathrm{max}$ of $70 \mathrm{ml} \cdot \mathrm{kg}^{-1} \cdot \mathrm{min}^{-1}$ sustains at $90 \%$ for $10,000 \mathrm{~m}$ (i.e., $63 \mathrm{ml} \cdot \mathrm{kg}^{-1} \cdot \mathrm{min}^{-1}$ ) and a running economy of $190 \mathrm{ml} \cdot \mathrm{kg}^{-1} \cdot \mathrm{km}^{-1}$ translates to a sustainable speed of $19.9 \mathrm{~km} / \mathrm{hr}$ [(63 $\times 60) / 190]$ and an expected 10,000-m time of 30:09 min:s.

A high $\mathrm{VO}_{2}$ max sets the ceiling on success in "submaximal" distance events (Saltin \& Astrand, 1967). Elite female distance athletes typically possess values of $65-80 \mathrm{ml} \cdot \mathrm{kg}^{-1} \cdot \mathrm{min}^{-1}$, whereas 
Table 1 Characteristics of Key Distance Events in Athletics

\begin{tabular}{|c|c|c|c|c|c|c|}
\hline Event & $\begin{array}{l}10,000-m \text { track } \\
\text { race }\end{array}$ & Cross country & $\begin{array}{l}\text { 21.1-km half } \\
\text { marathon }\end{array}$ & 20-km race walk & $\begin{array}{l}\text { 42.2-km } \\
\text { marathon }\end{array}$ & 50-km race walk \\
\hline $\begin{array}{l}\text { World record: male } \\
\text { (hr:min:s) }\end{array}$ & $\begin{array}{l}\text { 26:15:53 (Kenenisa } \\
\text { Bekele) }\end{array}$ & $\sim 12 \mathrm{~km}$ (no records) & $\begin{array}{l}\text { 58:18 (Abraham } \\
\text { Kiptum) }\end{array}$ & $\begin{array}{l}\text { 1:16:36 (Yusuki } \\
\text { Suzuki) }\end{array}$ & $\begin{array}{l}\text { 2:01:39 (Eliud } \\
\text { Kipchoge) }\end{array}$ & $\begin{array}{l}\text { 3:32:33 (Yohann } \\
\text { Diniz }\end{array}$ \\
\hline $\begin{array}{l}\text { World record: } \\
\text { female (hr:min:s) }\end{array}$ & $\begin{array}{l}\text { 29:17:45 (Almaz } \\
\text { Ayana) }\end{array}$ & $\sim 8 \mathrm{~km}$ (no records) & $\begin{array}{l}\text { 1:04:51 Joyciline } \\
\text { Jepkkosgei) }\end{array}$ & 1:24:38 (Hong Lui) & $\begin{array}{l}\text { 2:15:25 (Paula } \\
\text { Radcliffe) }\end{array}$ & 4:04:36 (Rui Liang) \\
\hline $\begin{array}{l}\text { Approximate inten- } \\
\text { sity }\left(\% \mathrm{VO}_{2} \max \right)\end{array}$ & $\begin{array}{l}90-95 \% \\
\geq \text { Critical speed }\end{array}$ & $\begin{array}{l}90-95 \% \\
\geq \text { Critical speed }\end{array}$ & $\begin{array}{l}85-90 \% \\
\leq \text { Critical speed }\end{array}$ & $\begin{array}{l}80-90 \% \\
\leq \text { Critical speed }\end{array}$ & $\begin{array}{l}80-85 \% \\
<\text { Critical speed but } \\
\text { above lactate } \\
\text { threshold }\end{array}$ & $\begin{array}{l}75-80 \% \\
\leq \text { Lactate threshold } \\
\text { unless during higher } \\
\text { intensity pieces }\end{array}$ \\
\hline Surface & Track & $\begin{array}{l}\text { Natural terrain, } \\
\text { with undulating } \\
\text { topography and } \\
\text { variable surfaces }\end{array}$ & $\begin{array}{l}\text { Road-may include } \\
\text { changes in elevation }\end{array}$ & $\begin{array}{l}1 \text { - to } 2-\mathrm{km} \text { circuit on } \\
\text { road-typically flat }\end{array}$ & $\begin{array}{l}\text { Road-may include } \\
\text { changes in elevation }\end{array}$ & $\begin{array}{l}\text { 2-km circuit on road } \\
\text { - typically flat }\end{array}$ \\
\hline $\begin{array}{l}\text { Physiological and } \\
\text { nutrition limitations } \\
\text { to performance }\end{array}$ & $\begin{array}{l}\text { Fatigue related to } \\
\text { peripheral factors } \\
\text { (metabolic acidosis, } \\
\mathrm{Ca}^{2+} \text { handling, } \\
\text { and low } \\
\text { phosphocreatine), } \\
\text { plus possible } \\
\text { localized } \\
\text { fiber-specific } \\
\text { glycogen depletion }\end{array}$ & $\begin{array}{l}\text { Fatigue related to } \\
\text { peripheral factors } \\
\text { (metabolic acidosis, } \\
\mathrm{Ca}^{2+} \text { handling, } \\
\text { and low } \\
\text { phosphocreatine), } \\
\text { plus possible } \\
\text { localized } \\
\text { fiber-specific } \\
\text { glycogen depletion }\end{array}$ & $\begin{array}{l}\text { Fatigue related to } \\
\text { glycogen depletion, } \\
\text { central fatigue, and } \\
\text { some peripheral } \\
\text { factors }\end{array}$ & $\begin{array}{l}\text { Fatigue related to } \\
\text { glycogen depletion, } \\
\text { central fatigue, and } \\
\text { some peripheral } \\
\text { factors }\end{array}$ & $\begin{array}{l}\text { Fatigue related to } \\
\text { glycogen depletion, } \\
\text { hypoglycemia, } \\
\text { possible } \\
\text { dehydration, } \\
\text { hyperthermia } \\
\text { depending on } \\
\text { environmental } \\
\text { conditions, and } \\
\text { central fatigue, } \\
\text { possibly muscle } \\
\text { damage }\end{array}$ & $\begin{array}{l}\text { Fatigue related to } \\
\text { glycogen depletion, } \\
\text { hypoglycemia, } \\
\text { possible } \\
\text { dehydration, } \\
\text { hyperthermia } \\
\text { depending on } \\
\text { environmental } \\
\text { conditions, and } \\
\text { central fatigue }\end{array}$ \\
\hline
\end{tabular}

elite male athletes possess higher values $\left(70-85 \mathrm{ml} \cdot \mathrm{kg}^{-1} \cdot \mathrm{min}^{-1}\right.$; Joyner \& Coyle, 2008), due to factors including higher hemoglobin concentrations, which increase $\mathrm{O}_{2}$ delivery at the maximal cardiac output, and lower fat mass. The fraction of $\dot{\mathrm{VO}}_{2}$ max that can be sustained for a given exercise duration, which is rarely $>90 \%$ $\dot{\mathrm{VO}}_{2}$ max in distance events, is related to muscle oxidative capacity (Gollnick \& Saltin, 1982; Ivy et al., 1980) and, in turn, metabolic thresholds, such as lactate threshold (LT; the speed corresponding to the first increase in blood lactate above resting levels; and critical speed $[\mathrm{CS}]$ ) and the asymptote of the hyperbolic relationship between speed and time-to-exhaustion (Hughson et al., 1984; Poole et al., 1988). Exercise above LT incurs a nonlinear increase in metabolic, respiratory, and perceptual stress and a more rapid fatigue development due to the effects of metabolic acidosis on contractile function or an accelerated depletion of muscle glycogen (Sahlin, 1992). A rightward shift in the blood [lactate]-speed relationship with training is a clear marker of enhanced endurance capacity (Hurley et al., 1984). However, LT typically occurs between $60 \%$ and $80 \% \dot{\mathrm{VO}}_{2}$ max even in highly trained individuals; a lower intensity than this is maintained during most distance races, except perhaps the 50-km walk. CS, representing the highest speed at which $\dot{\mathrm{V}}_{2} \max$ (and blood [lactate]) can be stabilized over time, may be more important. Elite athletes sustain $\sim 96 \%$ of CS during the marathon (Jones \& Vanhatalo, 2017), while a 10,000-m track event likely exceeds CS, at least for some portions of the race, such that the performance depends on the interplay between CS and the curvature constant of the speed-time relationship (Jones \& Vanhatalo, 2017). Physiological responses to exercise performed within moderate- $(<\mathrm{LT})$, heavy- $(>\mathrm{LT}$ but $<\mathrm{CS})$, and severe $(>\mathrm{CS})$ intensity domains differ considerably (Poole et al., 2016) with implications for the predominant cause(s) of fatigue (Black et al., 2017). The goal of race nutrition is to address the factors that would otherwise cause fatigue or suboptimal outputs during and especially toward the end of an event (Burke \& Hawley, 2018). Table 1 indicates that substrate availability for the muscle (glycogen and glucose) and brain (glucose) is a key issue for many distance events, along with the offset of sweat loss to preserve plasma volume and cardiac output.

There is variability in running and walking economy, defined as the steady-state $\mathrm{VO}_{2}$ at a given absolute speed, even between individuals with similar $\dot{\mathrm{VO}}_{2} \mathrm{max}$ and/or performance characteristics (Conley \& Krahenbuhl, 1980; Morgan \& Craib, 1992). Better exercise economy is advantageous to endurance performance because a lower fraction of $\mathrm{VO}_{2}$ max is utilized for any particular speed. Running economy is associated with anthropometric (including segmental mass distribution), physiological, metabolic, biomechanical, and technical factors (Saunders et al., 2004). Endurance training may improve exercise economy via improved muscle oxidative capacity and associated changes in motor unit recruitment patterns, reductions in exercise ventilation and heart rate for the same exercise intensity, and improved technique (Saunders et al., 2004; Williams \& Cavanagh, 1997). A partial offset may occur due to increased fat utilization because of its greater $\mathrm{O}_{2}$ requirement for adenosine triphosphate synthesis compared with $\mathrm{CHO}$ metabolism.

\section{Support for the Periodized Training Programs of Distance Athletes}

"Periodized nutrition," the strategic combination of nutrition and exercise to optimize training adaptations and competition performance (Jeukendrup, 2017a), is explained in relation to Athletics by Stellingwerff et al. (2019). In distance events, a variety of strategies, often in apparent conflict with each other but nevertheless targeted at enhancing the specific session or training phase, should be integrated into the annual, meso, and microcycles of training according to the athletes' individualized and changing goals. For example, workouts/ 
Table 2 Nutrition Strategies for High-Performance Athletes in Key Distance Events in Athletics

\begin{tabular}{|c|c|c|c|c|c|c|}
\hline $\begin{array}{l}\text { Issues and general } \\
\text { guidelines }\end{array}$ & $\begin{array}{l}10,000-\mathrm{m} \\
\text { track race }\end{array}$ & $\begin{array}{l}10-k m \text { cross } \\
\text { country }\end{array}$ & $\begin{array}{l}\text { 21.1-km half } \\
\text { marathon }\end{array}$ & 20-km race walk & $\begin{array}{l}\text { 42.2-km } \\
\text { marathon }\end{array}$ & 50-km race walk \\
\hline 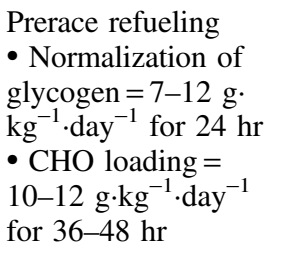 & $\begin{array}{l}\text { Glycogen } \\
\text { normalization }\end{array}$ & $\begin{array}{l}\text { Glycogen } \\
\text { normalization }\end{array}$ & $\begin{array}{l}\text { Glycogen } \\
\text { normalization }\end{array}$ & $\begin{array}{l}\text { Accentuated } \\
\text { glycogen } \\
\text { normalization }\end{array}$ & $\begin{array}{l}\text { CHO loading, } \\
\text { especially with } \\
\text { a low-residue } \\
\text { diet }\end{array}$ & $\begin{array}{l}\text { CHO loading, } \\
\text { especially with } \\
\text { a low-residue diet }\end{array}$ \\
\hline $\begin{array}{l}\text { Prerace meal } \\
\cdot 1-4 \mathrm{~g} \cdot \mathrm{kg}^{-1} \mathrm{CHO} \\
\text { in } 1-\text { to } 4-\mathrm{hr} \text { prerace }\end{array}$ & $\begin{array}{l}\text { Familiar } \\
\text { prerace meal }\end{array}$ & $\begin{array}{l}\text { Familiar } \\
\text { prerace meal }\end{array}$ & $\begin{array}{l}\text { Familiar prerace } \\
\text { meal + CHO after } \\
\text { warm-up }\end{array}$ & $\begin{array}{l}\text { Familiar prerace } \\
\text { meal + CHO after } \\
\text { warm-up }\end{array}$ & $\begin{array}{l}\text { Familiar prerace } \\
\text { meal + CHO after } \\
\text { warm-up }\end{array}$ & $\begin{array}{l}\text { Familiar prerace } \\
\text { meal + CHO after } \\
\text { warm-up }\end{array}$ \\
\hline
\end{tabular}

- Reduced fat, fiber, and

protein intake according to the risk of gut issues during the race

Opportunities for in-race nutrition (availability of drink stations)

In-race fueling goals

- 45-75 min: mouth

rinse/small $\mathrm{CHO}$

amount

- 1-2.5 hr: 30-60 g/hr

In-race hydration goals

- Aim to keep net fluid deficit $<2 \%$ to $3 \%$ body mass, especially in hot weather
- >2.5 hr: up to $90 \mathrm{~g} / \mathrm{hr}$

Nil Nil

(if extremely

hot, water

stations may be provided on an outside lane of the track if extremely hot)

N/A N/A

N/A N/A

Caffeine suppleme
- $3 \mathrm{mg} / \mathrm{kg}$ before/
during race

Special issues for hot weather events
Consider prerace precooling with ice slurry in addition to external cooling strategies if a significant thermal challenge is anticipated
Special comments for nonelite competitors
Prerace caffeine Prerace caffeine
Cost-benefit analy- Drink stations sis may show that allow plentiful time cost of drink- opportunities for ing may negate frequent small benefits in elite intakes of CHOrunners

Caffeine prerace and/or during race containing fluid toward a race plan

Caffeine prerace and/or during race

Consider prerace precooling with ice slurry in addition to external cooling strategies if a significant thermal challenge is anticipated

Consider prerace hyperhydration if a large fluid deficit is anticipated Adjust fluid intake during an event where possible in view of increased sweat losses

Do not overdrink by consuming fluid in Do not overdrink by consuming fluid in excess of sweat losses drink large opportunities for intakes of CHO-
Every lap of 2-km $5 \mathrm{~km}$ in elite races. loop course Frequency differs in large city marathons: may be every 2-3 km

30-60 g/hr CHO; Target an intake of consider a trialing $\quad 60-90 \mathrm{~g} / \mathrm{hr}$ from intake of up to the mix of $\mathrm{CHO}$ $90 \mathrm{~g} / \mathrm{hr}$ from the drinks or more mix of $\mathrm{CHO}$ drinks concentrated and more concen- gels/confectionary trated gels/ according to the confectionery fluid goals in race plan

Fast runners will Drink stations allow find it difficult to plentiful volumes frequent small containing fluids toward a race plan

Caffeine prerace Caffeine prerace and/or during race and/or during race to $3-6 \mathrm{mg} / \mathrm{kg}$ target to $3-6 \mathrm{mg} / \mathrm{kg}$ target

Consider prerace precooling with ice slurry in addition to external cooling strategies but take care with pacing strategies

Consider prerace hyperhydration if a large fluid deficit is anticipated Adjust fluid intakes during an event where possible in view of increased sweat losses excess of sweat losses

Note: All strategies should involve a personalized and well-practiced plan that is suited to the specific needs of the events. General guidelines can be found in more detail in Thomas et al. (2016). $\mathrm{CHO}=$ carbohydrate; $\mathrm{N} / \mathrm{A}=$ not available.

phases targeting an enhancement of oxidative capacity should exploit the superior adaptations in fat metabolism and mitochondrial biogenesis following exercise with low $\mathrm{CHO}$ availability either at a whole-body level or muscle level (Burke et al., 2018c; Jeukendrup, 2017a). Conversely, quality/high-intensity training should be performed with high $\mathrm{CHO}$ availability, as it is during the races (Jeukendrup, 2017a). Furthermore, when intake during the event is beneficial, it may be possible to prepare the gut to optimize and tolerate this by practicing strategies with adjusted intakes of $\mathrm{CHO}$ and fluid within the training sessions (Jeukendrup, 2017b). 


\section{Table 3 Summary of a "Low-Residue" (Low-Fiber) Diet}

\begin{tabular}{|c|c|}
\hline Characteristic & Comment \\
\hline Background & $\begin{array}{l}\text { - Used as a more acceptable alternative to a "clear liquid" diet or pharmaceutical preparation to reduce intestinal fecal } \\
\text { matter and secretions prior to bowel investigations or surgery (Vanhauwaert et al., 2015). } \\
\text { - Although the terms "low residue" and "low fiber" are often used interchangeably to describe this dietary practice, it has } \\
\text { been argued that it is best described as a low-fiber diet, with daily intakes }<10 \text {-g fiber (Vanhauwaert et al., 2015). }\end{array}$ \\
\hline $\begin{array}{l}\text { Application to athlete } \\
\text { practice }\end{array}$ & $\begin{array}{l}\text { - The implementation and outcomes have not been subjected to rigorous scientific investigation in sporting scenarios. } \\
\text { However, the acute use of low-fiber diets is often observed in weight division sports (Reale et al., 2017). Here, the } \\
\text { athletes suddenly reduce their fiber consumption in the days before weigh-in, in the belief or experience that a reduction } \\
\text { in bowel contents contributes a small but potentially valuable loss of body mass, with fewer disadvantages to the dietary } \\
\text { preparation for competition than food restriction. } \\
\text { - The reduction in body mass associated with this dietary practice in athletes is highly variable and individualistic (Reale } \\
\text { et al., 2017), but an average response of } ~ 500 \mathrm{~g} \text { might be expected (L.M. Burke, personal observations). } \\
\text { - Additional benefits of a prerace reduction in intestinal fiber content for distance runners and walkers include a lowered } \\
\text { risk of gut discomfort/upset during the race and simplification of the logistics of bowel evacuations in the hours prior to a } \\
\text { race. } \\
\text { - The optimal period of implementation of the prerace low-fiber diet is also highly variable and ranges from } 24 \mathrm{ho} 72 \mathrm{hr} \\
\text { depending on individual gut transit times (Reale et al., 2017). } \\
\text { - Disadvantages of the prerace low-fiber diet include a lack of food variety, a (short-term) reduction in dietary quality/ } \\
\text { micronutrient density and discomfort due to lower satiety/hunger. }\end{array}$ \\
\hline $\begin{array}{l}\text { Suggested implementation } \\
\text { of prerace low-fiber diet }\end{array}$ & $\begin{array}{l}\text { - The distance athlete should experiment with the duration of the low-fiber diet to determine an optimal plan according to } \\
\text { their usual fiber intake, gut transit time and personal tolerance of limited food variety, and reduced satiety/hunger. } \\
\text { - The diet can be integrated with a carbohydrate-loading protocol and may even assist with the achievement of targets for } \\
\text { large amounts of carbohydrate intake due to the increased energy density of food choices. } \\
\text { - Meals and snacks should be based on low-fiber, CHO-rich foods and the avoidance of significant sources of resistant } \\
\text { starch. Suitable foods include the following: } \\
\text { O "White" bread } \\
\text { "White" breakfast cereals (e.g., rice puffs) } \\
\text { O Sweetened dairy products } \\
\text { "White" rice, pasta, noodles, and potato: these should be well cooked and consumed hot to avoid the creation of } \\
\text { resistant starch with cooling } \\
\text { O Pulp-free fruit juice and sugary drinks (e.g., soda) } \\
\text { O Confectionary, jelly preserves, and honey } \\
\text { O Cakes and desserts based on white flour (e.g., cakes, puddings) and sugar (e.g., jello) but the avoidance of dried or } \\
\text { fresh fruit } \\
\text { - Sports products (e.g., sports drinks, gels, confectionary) } \\
\text { - Meat, milk, cheese, poultry, fish, eggs, and other protein-rich foods can be added to meals and snack menus. } \\
\text { added in modest amounts to make up meals or menu items; these include the following: } \\
\text { O Pureed fruit and apple sauce } \\
\text { O Mashed/pureed vegetables with a preference for "ketchup" style sauces and canned/mashed vegetables }\end{array}$ \\
\hline
\end{tabular}

It is likely that the heavy training loads and habitual dietary practices of high-performance distance runners/walkers, including the remarkable East African athletes (Commentary 1), already create periodization of $\mathrm{CHO}$ availability across a training cycle. Whether more deliberate planning can improve the outcome is of interest. In this regard, although subelite endurance athletes performed better after undertaking 3 weeks of training with strategic manipulations of CHO availability (Marquet et al., 2016), a study of elite race walkers failed to find evidence of superior race performance after an intensified training block supported by periodized $\mathrm{CHO}$ availability compared with constant high $\mathrm{CHO}$ availability (Burke et al., 2017). Meanwhile, both dietary approaches were associated with better race outcomes than chronic (3.5 week) exposure to a ketogenic low $\mathrm{CHO}$, high-fat diet, despite its achievement of substantial $(\sim 2.5 \times)$ increases in muscle fat oxidation (Burke et al., 2017). This contrasts with claims that a low $\mathrm{CHO}$, high-fat diet is the "future of elite endurance sport" but is supported by empirical (Krogh \& Lindhard, 1920) and theoretical (Leverve et al., 2007) evidence of better exercise economy with $\mathrm{CHO}$-dependent generation of adenosine triphosphate than fat oxidation pathways (see Commentary 2 for modeling of this effect). This is especially important at exercise intensities that are typical of the distance events (Hawley \& Leckey, 2015). Further investigation of periodization of fuel support strategies in elite athletes is warranted, although it is clear that some areas are controversial or confusing. This is at least partly attributable to different definitions or inaccurate descriptions of the implementation or goals of these strategies. A recent commentary has promoted the case for a common terminology and understanding of this theme (Burke et al., 2018c). In the meantime, it appears that elite athletes include various versions of "train high," "train low," and "gut training" within their training programs, both accidentally and intentionally (Heikura et al., 2018; Stellingwerff, 2012).

Periodization of body composition provides another example of strategic integration of different nutrition strategies within the training schedules. A recent science-based case study of an Olympic female middle-distance runner argued that it is not sustainable from a health and/or performance perspective to be at ideal race body composition year-round (Stellingwerff, 2018). Instead, an assessment of anthropometric, hematological, and performance metrics over a 9-year career demonstrated a periodized approach. During the general preparation phase (SeptemberApril), the athlete was $\sim 2-4 \%$ over ideal race body mass (BM) and 
body fat $(\%)$, with optimal energy availability being prioritized. Body composition optimization for competition (May-August) included an individualized time frame and energy deficit with various feedback metrics (BM, performance, and hunger) to guide the process. This approach supported targeted peak performances and minimized risk of injury while maximizing training adaptation and long-term athlete health through management of energy availability. Although this concept has, arguably, been understood for many years, the concept and calculated practice is a contemporary update (Jeukendrup, 2017a). Importantly, it helps the athlete to integrate the inevitability or benefits of brief periods of controlled low energy availability within the endurance training framework. Problems associated with chronic or severe low energy availability, known as relative energy deficiency in sports, are well known (Mountjoy et al., 2018); specific issues in relation to Athletics are covered by Melin et al. (2019).

\section{Race Preparation}

Race preparation should include strategies to store muscle glycogen in the amounts commensurate with the fuel needs of the event. For races <90-min duration (e.g., 10,000-m track race, cross country, half marathon, and $20-\mathrm{km}$ walks), it is sufficient to normalize the superior glycogen concentrations associated with endurance training; this is typically achieved with CHO intakes of 7-10 g/ $\mathrm{kg} \mathrm{BM}$ for $24 \mathrm{hr}$ (Burke et al., 2011). In the marathon and 50-km race walk where glycogen can become limiting for race performance, the protocols that supercompensate glycogen are beneficial. Indeed, investigations of the original protocol devised in the 1960s involving distance runners (Karlsson \& Saltin, 1971) and race walkers (Hyman, 1970) were largely responsible for the popularization of this strategy within the sports world; these studies showed that $\mathrm{CHO}$ loading improved performance by attenuating the decay in speed in the last part of the race. The contemporary $\mathrm{CHO}$ loading protocol is an abbreviated version of the original involving 36-48 hr of $\mathrm{CHO}$ intakes targeting $10-12 \mathrm{~g} \cdot \mathrm{kg}^{-1} \cdot \mathrm{day}^{-1}$ (Burke et al., 2011). This is often undertaken in conjunction with a low residue (fiber) diet (Table 3), which may not only reduce the risk of gut issues during the race but also achieve a small reduction in BM to partially offset the mass of the additional muscle glycogen and stored water.

Further contributions to fuel availability are provided by a preevent CHO-focused meal and a small CHO-rich snack (e.g., sports gel or drink) during the race warm-up. This is particularly important for events undertaken in the morning where $\mathrm{CHO}$ intake can restore liver glycogen following an overnight fast as well as provide an ongoing supply of $\mathrm{CHO}$ from the gut (Burke et al., 2011). The timing, size, and food choices in the prerace meal will vary according to event characteristics and athletes' preferences; these should be well practiced to develop an individualized protocol. Athletes should also consider fluid needs to achieve optimal hydration status for the event and specific race conditions (see Casa et al., 2019). As discussed in the section on racing in the heat, there may also be opportunities to address race challenges related to thermoregulation and dehydration by hyperhydrating and/or precooling in the hours prior to the event.

\section{Race Feeding: Fueling and Hydration Update}

Some distance events offer an opportunity for athletes to consume fluid and fuel during the race to address the physiological limitations of these factors (Table 2). CHO ingestion during longer distance events (e.g., marathon and 50-km race walk) can improve performance by delivering additional substrates to maintain high rates of $\mathrm{CHO}$ oxidation in the face of dwindling endogenous stores (Coyle et al., 1986). A systematic review of the literature on $\mathrm{CHO}$ ingestion during endurance protocols by Stellingwerff and Cox (2014) concluded that $82 \%$ of studies (50 of 61 studies, involving 679 subjects) showed statistically significant benefits from this practice. Older guidelines (Coyle, 1991) recommended that distance athletes should experiment with hourly $\mathrm{CHO}$ intakes within the range of 30-60 $\mathrm{g}$ to find a beneficial strategy. More contemporary recommendations (Burke et al., 2011; Thomas et al., 2016), however, suggest smaller amounts for shorter duration events and higher rates of intake for longer events $(>2.5 \mathrm{hr})$, based on the mechanism of likely benefits to performance as well as the recognition that higher amounts can be tolerated and utilized than previously considered.

Early investigations of $\mathrm{CHO}$ ingestion during exercise concluded that maximal oxidation rates plateaued at $60 \mathrm{~g} / \mathrm{hr}$, even when larger amounts were ingested (120-180 g/hr; Jeukendrup, 2014). The limiting factor was subsequently found to be intestinal absorption, particularly the sodium-dependent glucose transporter, rather than gastric emptying, hepatic glucose extraction, muscle glucose uptake, or muscle glucose oxidation (Jeukendrup, 2014). However, as reviewed by Jeukendrup (2017b), sodium-dependent glucose transporter abundance and activity in animals is increased by a $\mathrm{CHO}$-rich diet; furthermore, chronic exposure to higher $\mathrm{CHO}$ intakes by athletes, including exercise intake, increases gut tolerance, intestinal absorption, and muscle oxidation of $\mathrm{CHO}$ consumed during exercise (Costa et al., 2017; Cox et al., 2010). Combining glucose-based $\mathrm{CHO}$ sources with fructose (transported in the intestine by GLUT5) increases total exogenous $\mathrm{CHO}$ oxidation during exercise, with rates as high as $1.75 \mathrm{~g} / \mathrm{min}$ (Jeukendrup \& Chambers, 2010). Narrative review (Stellingwerff \& Cox, 2014), meta-analysis (Vandenbogaerde \& Hopkins, 2011), and dose-response (Smith et al., 2010) approaches to this topic have found that higher amounts of $\mathrm{CHO}$ promote better performance in longer events relevant to the marathon and $50-\mathrm{km}$ race walk, with optimal intakes of 75-90 g/hr. However, in shorter events (half marathon, 20-km race walking), performance benefits may be associated with the intake of smaller amounts of $\mathrm{CHO}$, including central nervous system activation associated simply with mouth exposure to $\mathrm{CHO}$ (the socalled "mouth rinsing" effect). Indeed, there is robust evidence that the detection of $\mathrm{CHO}$ by receptors in the oral cavity, independent of sweetness, activates certain centers in the brain to enhance perceptions of effort and pacing decisions (see Jeukendrup \& Chambers, 2010). A range of sports drinks, gels, and confectionery is available to meet various targets, both in training and racing, around taste, practicality, balanced intake of fluid and $\mathrm{CHO}$, inclusion of multiple transportable $\mathrm{CHO}$ sources, electrolyte replacement, and supplementation with caffeine, while other everyday foods and drinks may also be used.

Fluid intake to address sweat losses is important during longer events and in the heat because a fluid deficit equivalent to $>2-3 \%$ $\mathrm{BM}$ loss is typically associated with increases in perception of effort and core temperature and reductions in performance, especially in hot environments (Sawka et al., 2015). However, plans for fluid intake in events that permit it (as indeed for $\mathrm{CHO}$ intake) should involve a cost-benefit analysis, where "costs" include the availability of supplies at drink stations during the race (see Table 2), the time lost while slowing down to obtain and consume drinks/sports products, and the risk of gut upsets. Furthermore, the 
associated BM reduction may partially compensate for the disadvantages of dehydration. High-performance runners are less able to consume fluid/CHO during the race than racewalkers because of the higher speed of movement and the lower number/increased time between drink stations; for example, $\sim 15-18 \mathrm{~min}$ for marathon runners with stations every $5 \mathrm{~km}$ versus $8-10 \mathrm{~min}$ for racewalkers with stations every $2 \mathrm{~km}$. Furthermore, the impracticality of drinking large volumes despite high sweat rates explains BM losses of up to $10 \%$ in race winners in hot-weather marathons (e.g., Beis et al., 2012). We recommend that athletes develop a personalized and practiced race plan that optimizes fluid and $\mathrm{CHO}$ status within the prevailing conditions and opportunities of each event. Despite the practical challenges, the authors of this paper have assisted several elite athletes to break Olympic and world records/marks using aggressive hydration and $\mathrm{CHO}$ feeding plans (targeting $90 \mathrm{~g} / \mathrm{h}$ ); some of which have been described independently ( Caesar, 2017; Hutchinson, 2017). Indeed, some recent elite marathons, including the 2018 Berlin event in which the most recent world record was set, have increased the frequency of feed zones (every $2.5 \mathrm{~km}$ ) to provide greater opportunity for race feeding. A personalized drinking plan can be adjusted to all levels of runners, including recreational competitors who may drink in volumes exceeding their sweat rates and who should be warned about the dangers of developing hyponatremia (Almond et al., 2005).

\section{Supplements for Distance Athletes}

The term "supplements' includes products that address a distance athlete's nutrition goals in a specialized context: medical supplements used to prevent/treat a nutrient deficiency (e.g., vitamin D or iron supplements); sports foods providing energy, macronutrients, and fluid requirements in scenarios where whole foods are impractical; and performance supplements that directly improve training or competition outcomes. Characteristics of these products and scenarios in which they contribute to a distance athlete's nutrition plan are summarized elsewhere (Castell et al., 2019; Maughan et al., 2018; Peeling et al., 2019). The specific needs of long-distance races raise potential new uses of sports foods and performance supplements, based on the specific physiological, biochemical, and central nervous system factors that limit performance in these races, as well as the opportunity to consume products within the event, at least for races of half marathon and longer.

Only a handful of the multitude of performance supplements marketed to athletes have a strong evidence base. Peeling et al. (2019) have separately reviewed these products (caffeine, nitrate, creatine, $\beta$-alanine, and bicarbonate) and their mechanisms of action in relation to Athletics, identifying only the first two of this group as likely to achieve a performance benefit in distance events; investigations of these products in relevant scenarios are summarized in Tables 4 and 5 . We note the sparsity of specific studies and the variability in findings; this may arise from differences in supplement protocols as well as the underpowering of studies due to small sample sizes and/or reliance on performance protocols lacking sufficient reliability to detect small but meaningful benefits. Indeed, the evidence base for these performance products relies on summaries of the general endurance sports literature (McMahon et al., 2017; Southward et al., 2018a). However, the actual use of any performance supplement by endurance athletes requires its integration into a bespoke nutrition plan that accounts for the specificity of their event and/or training schedule and their experience of individual responsiveness to the plan (Burke et al., 2018a).
Table 2 summarizes the role of sports foods/drinks in achieving the goals for $\mathrm{CHO}$ and fluid intake during distance events. While the known benefits of these strategies provide a benchmark against which the magnitude of any effects from other performance products should be compared, these also provide a potential confounder of the effectiveness of other performance supplements. For example, a meta-analysis of a heterogeneous group of studies of caffeine supplementation and endurance performance (Conger et al., 2011) found that the margin of improvement when caffeine was consumed in addition to $\mathrm{CHO}$ was significantly reduced (but still worthwhile) in comparison to scenarios involving a water placebo (mean effect sizes $=0.26$ vs. $0.52, p=.006$ ). This illustrates why potential interactions between concurrently used supplements or nutrition strategies are of high priority for scientific investigation and specific consideration when developing race plans or training uses (Burke et al., 2018d). The efficacy of caffeine during endurance sports may be correlated with its role in masking fatigue (Spriet, 2014); therefore, in situations in which another strategy reduces the onset or magnitude or fatigue, a smaller effect on performance is logical. Conversely, in scenarios of increased fatigue such as "training low" with endogenous CHO stores, caffeine may provide a greater benefit in helping to attenuate the reduction in training capacity (Lane et al., 2013). Other issues associated with caffeine or nitrate use in distance Athletics are noted in Tables 4 and 5. Finally, the potential for enhanced glycogen storage following creatine supplementation (Roberts et al., 2016) merits further investigation in terms of increased $\mathrm{CHO}$ availability for the longer distance races; however, such benefits should be balanced against the likely increase in BM (Tomcik et al., 2017).

\section{Strategies for Hot Environments}

Major championships are often held in hot and/or humid environments, with the Doha 2019 World Championships and Tokyo 2020 Olympic Games being the immediate targets at the time of preparation of this review. There are multiple and circular interactions between the hot environment and nutrition; exercise in the heat creates extra challenges in terms of increased rates of fluid loss and glycogen use (Jentjens et al., 2002), with dehydration increasing the risk of gastrointestinal discomfort/upset (Rehrer et al., 1990) and further interference with nutrition status and goals. Meanwhile, fluid intake reduces thermal stress (Montain \& Coyle, 1992), and CHO intake reduces gut damage (Snipe et al., 2017). The performance and health challenges associated with racing in hot weather should be addressed by strategies, such as acclimatization, appropriate pacing, and precooling activities (Racinais et al., 2015). Adjustment to race nutrition strategies, if practical, may also assist (Table 2). For example, a more aggressive approach to in-race hydration strategies to address greater fluid losses may be possible, while hyperhydration during the hours before a race via the consumption of large amounts of fluid together with an osmotic agent (e.g., glycerol or sodium) can reduce the net fluid deficit incurred over the race (Goulet et al., 2007; van Rosendal \& Coombes, 2013). Here, we note that glycerol has been removed from the World Anti-Doping Agency's list of prohibited substances and may be reinstated for use in hyperhydration/rehydration strategies. The intake of ice slurries within precooling strategies to reduce prerace core temperature via the "heat sink" created by the phase change from ice to water may also be beneficial (Jay \& Morris, 2018; Ross et al., 2013). Where in-race fluid intake is practical, mouth sensing of cold water or menthol may provide a sense of cooling during a race to reduce ratings of 
Table 4 Summary of Caffeine Supplementation and Performance of Distance Events

\begin{tabular}{ll}
\hline Overview (see Burke, 2008; Southward et al., 2018a; Spriet, 2014) \\
\hline $\begin{array}{l}\text { Mechanism of } \\
\text { action }\end{array}$ & $\begin{array}{l}\text { - Adenosine receptor antagonist with a large range of effects } \\
\text { - Major effects during endurance exercise include masking of perception of effort, fatigue and pain, and increase in vigilance and } \\
\text { alertness }\end{array}$ \\
\hline $\begin{array}{l}\text { Best practice } \\
\text { protocol }\end{array}$ & $\begin{array}{l}\text { - } 3 \mathrm{mg} / \mathrm{kg} \text { (up to } 6 \mathrm{mg} / \mathrm{kg}) \text { taken before and/or during distance events, with sources including food (e.g., coffee, cola drinks, energy } \\
\text { drinks), sports foods (e.g., caffeinated gels), or pharmaceutical products (e.g., caffeine tablets) }\end{array}$ \\
& $\begin{array}{l}\text { Greater responsiveness to small amounts of caffeine (2-3 mg/kg) may be seen when it is taken during a race, around the onset of } \\
\text { fatigue (Spriet, 2014) }\end{array}$ \\
\hline $\begin{array}{l}\text { Issues for } \\
\text { future study }\end{array}$ & $\begin{array}{l}\text { - Individual responsiveness to caffeine supplementation in distance running, including genetic causes (Southward et al., 2018b) } \\
\text { - Interaction with other supplements-CHO, nitrate }\end{array}$ \\
& $\begin{array}{l}\text { Effect of caffeine on heat storage and performance in hot, humid environments (Hanson et al., 2018) } \\
\text { (e.g., altitude training, training with low CHO availability; Lane et al., 2013) }\end{array}$
\end{tabular}

\begin{tabular}{|c|c|c|c|c|c|}
\hline Investigations & Study design & Caffeine protocol & $\begin{array}{l}\text { Performance } \\
\text { protocol }\end{array}$ & Effect & Comments \\
\hline Cohen et al. (1996) & $\begin{array}{l}\text { - Competitive distance } \\
\text { runners }(5 \mathrm{M}+2 \mathrm{~F}) \\
\text { - Crossover design with } \\
\text { different caffeine } \\
\text { doses vs. placebo }\end{array}$ & $\begin{array}{l}\text { - } 5 \text { and } 9 \mathrm{mg} / \mathrm{kg} \\
\text { taken prerace }\end{array}$ & $\begin{array}{l}\text { - Half marathon } \\
\text { (field study) } \\
\text { - Hot conditions } \\
\text { - Water during run }\end{array}$ & $\begin{array}{l}\text { No benefit } \\
\text { detected }\end{array}$ & $\begin{array}{l}\text { No effects on RPE or } \\
\text { performance at either dose } \\
\text { compared with placebo }\end{array}$ \\
\hline $\begin{array}{l}\text { Van Nieuwenhoven } \\
\text { et al. (2005) }\end{array}$ & $\begin{array}{l}\text { - Trained to } \\
\text { well-trained runners } \\
(90 \mathrm{M}+8 \mathrm{~F}) \\
\text { - Crossover design with } \\
\text { caffeine + CHO vs. } \\
\text { CHO vs. water } \\
\text { placebo }\end{array}$ & $\begin{array}{l}\text { - } 1.3 \mathrm{mg} / \mathrm{kg} \text { in } 7 \% \\
\mathrm{CHO} \text { drink vs. } \mathrm{CHO} \\
\text { drink alone } \\
\text { - } 600-\mathrm{ml} \text { drink } \\
\text { consumed in equal } \\
\text { portions before and at } \\
4.5-, 9-\text {, and } 13.5-\mathrm{km} \\
\text { race }\end{array}$ & $\begin{array}{l}\text { 18-km road race } \\
\text { (field study) } \\
\text { - } \mathrm{CHO} \text { drink during run }\end{array}$ & $\begin{array}{l}\text { No benefit } \\
\text { detected }\end{array}$ & $\begin{array}{l}\text { No differences in performance of } \\
\text { whole group between caffeinated } \\
\text { sports drink }(78: 03 \pm 8: 42 \text { [min: } \\
\text { s]), sports drink }(78: 23 \pm 8: 47) \text {, or } \\
\text { water ( } 78: 03 \pm 8: 30) \text { or for } 10 \\
\text { fastest runners }(63: 41,63: 54 \text { vs. } \\
63: 50 \text { for caffeine sports drink, } \\
\text { sports drink, and water, } \\
\text { respectively). }\end{array}$ \\
\hline
\end{tabular}

Bridge and Jones

Relative to the mean time of the

\begin{tabular}{|c|c|c|c|}
\hline $\begin{array}{l}\text { Bridge and Jones } \\
(2006)\end{array}$ & $\begin{array}{l}\text { - Distance runners } \\
(8 \mathrm{M}) \\
\text { - Crossover design with }\end{array}$ & $\begin{array}{l}-3 \mathrm{mg} / \mathrm{kg} \text { taken } \\
60 \text {-min prerace }\end{array}$ & $\begin{array}{l}\text { - 8-km race on track } \\
\text { (field study) } \\
\text { - No intake during run }\end{array}$ \\
\hline
\end{tabular}

- Crossover design with

- No intake during run caffeine vs. placebo vs. control

control and placebo trials,

caffeine supplementation resulted

in a $23.8 \mathrm{~s}$ or $1.2 \%$ improvement

in run time $(p<.05)$ with individual results ranging from 10 to $61 \mathrm{~s}$ improvement. HR was significantly higher in caffeine trial, with a trend to lower RPE despite the faster running speed.

\begin{tabular}{llcl}
\hline $\begin{array}{l}\text { Potgieter et al. } \\
(2018)\end{array}$ & $\begin{array}{l}\text { Well-trained triath- } \\
\text { letes (14 M 12 F); }\end{array}$ & $6 \mathrm{mg} / \mathrm{kg}$ taken \\
& $\begin{array}{l}\text { Crossover design with } \\
\text { caffeine vs. placebo }\end{array}$ & $\begin{array}{l}\bullet 10-\mathrm{km} \text { run at the end Benefit } \\
\text { of Olympic distance detected } \\
\text { triathlon (field study) }\end{array}$
\end{tabular}
caffeine vs. placebo
Caffeine associated with a $1.3 \%$ improvement in race time $(149.6 \pm 19.8$ vs.

$151.5 \pm 18.6 \mathrm{~min}, p<.05)$, with great effect in male subjects. No difference in RPE despite faster time. Caffeine associated with greater blood lactate and cortisol concentrations.

No difference in $10-\mathrm{km}$ time $(53.2 \pm 8.2 ; 53.4 \pm 8.4 ; 52.7 \pm 8.2$ for placebo, $3 \mathrm{mg} / \mathrm{kg}$, and $6 \mathrm{mg} / \mathrm{kg}$ doses). However, a greater increase in core temperature with higher caffeine dose suggests greater heat storage.

Note. $\mathrm{TT}=$ time trial; $\mathrm{M}=$ male; $\mathrm{F}=$ female; $\mathrm{HR}=$ heart rate; $\mathrm{rh}=$ relative humidity; $\mathrm{RPE}=$ ratings of perceived exertion. 


\section{Table 5 Summary of Nitrate Supplementation and Effect on Performance of Distance Events}

\begin{tabular}{ll}
\hline Overview (for review, see Jones et al., 2018; McMahon et al., 2017) \\
\hline Mechanism of action & $\begin{array}{l}\text { - Improves exercise economy (reduces the oxygen cost of submaximal exercise) to improve endurance exercise performance } \\
\text { - Enhances skeletal muscle contractile function to improve muscle power and sprint exercise performance }\end{array}$ \\
\hline Best practice protocol & $\begin{array}{l}\text { - } 8 \text { mmol nitrate taken 2- to 3-hr prerace, especially with chronic intake for 3+ days pretrial } \\
\text { - Usually taken in the form of beetroot juice concentrate }\end{array}$ \\
\hline Issues for future study & $\begin{array}{l}\text { - Individual responsiveness to nitrate supplementation in distance running, including the effect of athletes' caliber as it seems } \\
\text { less effective in elite athletes (Jonvik et al., 2015) } \\
\text { - Effect of protocols involving intake during distance events to maintain elevated plasma nitrite concentrations (Tan et al., } \\
\text { 2018) } \\
\text { - Interaction with other supplements - CHO, caffeine, etc. } \\
\text { - Effect of nitrate on heat storage and performance in hot, humid environments (Kent et al., 2018) } \\
\text { - Use of nitrate to promote training capacity/quality, including the use during altitude training }\end{array}$ \\
\hline
\end{tabular}

\begin{tabular}{|c|c|c|c|c|c|}
\hline Investigations & Study design & Nitrate protocol & $\begin{array}{l}\text { Performance } \\
\text { protocol }\end{array}$ & Effect & Comments \\
\hline Shannon et al. (2017) & $\begin{array}{l}\text { - Well-trained } \\
\text { runners/triathletes } \\
(8 \mathrm{M}) \\
\text { - Crossover design with } \\
\text { nitrate vs. placebo }\end{array}$ & $\begin{array}{l}-12.5 \mathrm{mmol} \\
\text { (beetroot juice) } \\
\text { taken 3-hr pretrial }\end{array}$ & $\begin{array}{l}\text { - } 10-\mathrm{km} \text { treadmill } \\
\text { TT }\end{array}$ & $\begin{array}{l}\text { No benefit } \\
\text { detected }\end{array}$ & $\begin{array}{l}\text { No difference in } 10,000-\mathrm{m} \text { TT between } \\
\text { nitrate vs. placebo }(2,643 \pm 324 \text { vs. } \\
2,650 \pm 320 \mathrm{~s}, p>.05) \text {, although the } \\
\text { same athletes performed better on a } \\
1,500 \text {-m test in the same study. }\end{array}$ \\
\hline De Castro et al. (2019) & $\begin{array}{l}\text { - Recreational runners } \\
(14 \mathrm{M}) \\
\text { - Crossover design with } \\
\text { nitrate vs. placebo }\end{array}$ & $\begin{array}{l}\text { - 8 mmol (beetroot } \\
\text { juice) taken for } \\
3 \text { days and 2-hr } \\
\text { pretrial }\end{array}$ & $\begin{array}{l}\text { - } 10-\mathrm{km} \text { treadmill } \\
\text { TT }\end{array}$ & $\begin{array}{l}\text { No benefit } \\
\text { detected }\end{array}$ & $\begin{array}{l}\text { No difference between nitrate and } \\
\text { placebo }(50.1 \pm 5.3 \mathrm{vs} .51 .0 \pm 5.1 \mathrm{~min}, \\
p=.391) \text { for } 10 \mathrm{~km} \text {, although time to } \\
\text { complete the first } 5 \mathrm{~km} \text { was lower in the } \\
\text { nitrate group }(p=.027) \text {. }\end{array}$ \\
\hline
\end{tabular}

Note. $\mathrm{M}=$ male; $\mathrm{TT}=$ time trial $\mathrm{CHO}=$ carbohydrate.

perceived effort (Stevens \& Best, 2017), while intake of reasonable amounts of cold/icy beverages might theoretically contribute to improved thermoregulation (Jay \& Morris, 2018). The literature on the specific benefits of these strategies (see Table 6) in high-performance running or racewalking scenarios is sparse; an investigation is required, including the assessment of potential disadvantages such as an increase in BM or a greater risk of gut disturbances. In the meantime, athletes should practice the intended use of these strategies before implementing in a race.

\section{Commentary 1: Dietary Practices of East African Runners}

East African athletes have dominated distance running for decades, with their superior performance drawing speculation about a range of potential contributing factors (Larsen \& Sheel, 2015), including their striking dietary practices and specific anthropometric features (Burke et al., 2018b; Mooses \& Hackney, 2017). Although dietary surveys of Kenyan and Ethiopian runners have been limited to their home environments and training camps (Beis et al., 2011; Christensen et al., 2002; Fudge et al., 2006, 2008; Onywera et al., 2004), it appears that they maintain their eating practices on the competition circuit or in their Northern Hemisphere training bases because of the low cost and cultural familiarity, as well as self-belief that it might contribute to their success (M. Mooses, personal observations, Dec 10, 2018). A range of features, both consistent and in contrast to current sports nutrition guidelines, merit comment.

The diets of East African runners contain substantially different contributions of foods and macronutrients compared with Western practices; indeed, CHO supplies $60-80 \%$ of energy, with high reliance on vegetables (80-90\% of diet) rather than animal food sources (10-20\%), and limited food variety (staple foods: rice, pasta, potatoes, porridge, cabbage, kidney beans, ugali maize meal, and injera flatbread). Typical fluid choices include water (0.9-1.1 L/day) and tea ( $\sim 0.9$ L/day) with brown sugar and (for Kenyans) milk (Beis et al., 2011; Onywera et al., 2004). Daily energy intake is distributed over a small number of meals, with prolonged moderate- to fast-paced morning runs being undertaken before breakfast and with nil/minimal intake of fluid (Beis et al., 2011; Fudge et al., 2006, 2008; Onywera et al., 2004). Meanwhile, meals are consumed soon after training sessions, and high-intensity track sessions are completed as a midmorning workout after breakfast. Indeed, many concepts of periodizing $\mathrm{CHO}$ availability according to the needs of the session (Burke et al., 2018c) appear within these traditional practices. Although supplements are rarely used, data from observational studies (Beis et al., 2012) and accounts of recent attempts on world marathon records by male runners (Caesar, 2017; Hutchinson, 2013) note personalized race nutrition plans including proactive intakes of fluid and $\mathrm{CHO}$, often with the involvement of Western sports scientists.

Also of topical interest is the reported or suspected prevalence of acute or chronic periods of low energy availability among these athletes. Notwithstanding artifacts in dietary survey methodology and calculations of energy availability (Burke et al., 2018a), there are consistent reports of low energy intakes relative to calculated or expected exercise energy expenditures in various groups of East African middle- and long-distance athletes (Fudge et al., 2006, 2008; Onywera et al., 2004). Contributors to energy mismatches include cultural eating patterns (e.g., fiber-rich unvaried diet, few eating occasions in a day), food insecurity, and the interaction with high training loads (e.g., lack of intake during training hours, postexercise appetite suppression; Burke et al., 2018b). Although the role of deliberate manipulation of $\mathrm{BM} /$ composition for 


\section{Table 6 Summary of Hyperhydration and Cooling Strategies With Relevance to Events in Distance Athletics}

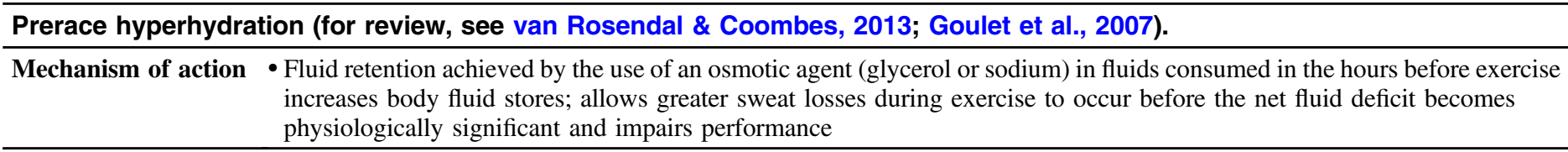

Best practice protocol $\bullet 25 \mathrm{ml} / \mathrm{kg}$ of fluid consumed $\sim 2$-hr pre-exercise with $\sim 1$-g/kg glycerol or 7-g sodium chloride; typically aids in the short-term retention of $\sim 600$-ml fluid to add to body water stores

Issues for future study • Which is the most effective osmotic agent? Can a combination of osmotic agents increase fluid retention?

- Does the gain in body mass associated with fluid gain create a performance disadvantage?

- What are the other side effects (e.g., headache, gut upsets) associated with hyperhydration strategies?

Ice slurry for precooling and within race cooling (for review, see Jay \& Morris, 2018; Ross et al., 2013)

\begin{tabular}{ll}
\hline Mechanism of action & $\begin{array}{l}- \text { Internal heat transfer from cold drink or the enthalpy of fusion of ice (phase change from solid to liquid) may reduce total } \\
\text { body heat content and allow greater duration or intensity of exercise before thermoregulatory challenges become significant } \\
\text { and impair performance }\end{array}$
\end{tabular}

Best practice protocol - Ice slurry: 14-ml/kg of fluid consumed in two servings in the 30-60 min pre-exercise (i.e., immediately before abbreviated race warm-up) to allow time to excrete excess fluid if needed. Should be combined with external cooling strategies (e.g., cold-water immersion or ice towels/vest) to provide additional effects, which might be continued during/after warm-up

Issues for future study - What is the most effective combination of internal and external cooling for each specific event, taking into account the logistical issues (timing of warm-up and race, facilities in race setting) as well as thermal challenges?

-What is the effect of precooling on pacing strategies? Can precooling be detrimental if athlete misjudges perception of effort in the early party of race and chooses an unsustainable intensity causing a higher thermal load than can be tolerated?

\begin{tabular}{ll} 
Mouth sensing of "cool" during race with menthol (for review, see Stevens \& Best, 2017) \\
\hline Mechanism of action & $\begin{array}{l}\text { - Exposure of L-menthol in the oral cavity activates transient receptor potential channels eliciting a cold sensory perception in } \\
\text { the brain } \\
- \text { Offers the opportunity to reduce thermal sensation/discomfort without changing body heat load to improve performance in } \\
\text { the heat }\end{array}$ \\
\hline Best practice protocol & $\begin{array}{l}- \text { Mouth rinsing or consumption of L-menthol in fluid or other agents (e.g., confectionery) } \\
\text { - May be potentiated when combined with a cool fluid }\end{array}$ \\
\hline Issues for future study & $\begin{array}{l}\text { - What is the optimal concentration and vehicle for mouth rinsing with menthol? } \\
- \text { Is the effect on thermal sensations repeatable throughout the race? } \\
- \text { Is there a danger, to health or performance, of using artificial sensations of "cooling" during exercise in the heat if the athlete } \\
\text { chooses a pace that leads to a higher thermal load }\end{array}$ \\
\hline
\end{tabular}

performance purposes is unclear, some involvement is likely because low energy intakes have been observed during precompetition training camps (Onywera et al., 2004), and the majority of African athletes report that their "ideal racing weight" is lower than their normal training BM (Mooses, personal observations, Dec 10, 2018).

Further study is needed to consolidate our understanding of the dietary practices of these highly successful athletes and how much they contribute to, or interfere with, optimal performance. It is likely that practices include both helpful and harmful features, as well as accidental and intentional elements. As for any group of athletes, an audit of practices may identify the potential for performance improvement, but various practical and personal issues need to be taken into account.

\section{Commentary 2: Modeling the 2-hr Marathon Barrier: Is $\mathrm{CHO}$ a Tool?}

Nearly 100 years ago, Krogh and Lindhard (1920) reported that energy derived from the metabolic consumption of $\mathrm{O}_{2}$ depends on whether fat or $\mathrm{CHO}$ is the primary source of carbon substrate. For example, increasing the respiratory quotient (RQ) from 0.85 to 0.90 ( $49 \%$ to $66 \%$ contribution from $\mathrm{CHO}$ ) results in a $5 \%$ increment in released energy (4.967 vs. 4.921 ; Krogh \& Lindhard, 1920). In the D.B. Dill lecture at the 2015 annual conference of the American College of Sports Medicine, Professor Ron Maughan identified the important implications of this finding for marathon performance; an increase in RQ improves metabolic efficiency by reducing the $\mathrm{O}_{2}$ cost of running at a particular speed or permitting a higher speed for the same absolute $\mathrm{VO}_{2}$. This contradicts the conventional recommendation that endurance athletes should spare their finite $\mathrm{CHO}$ reserves by maximizing the use of fat as a substrate. However, it is supported by the findings of an increased $\mathrm{O}_{2}$ cost of race walking at speeds related to race performance when rates of fat oxidation were markedly increased by adaptation to a ketogenic low CHO, high-fat diet (Burke et al., 2017).

With regard to the challenges of a sub-2-hr marathon, if we assume a running economy of $190 \mathrm{ml} \cdot \mathrm{kg}^{-1} \cdot \mathrm{km}^{-1}$ at $21.1 \mathrm{~km} / \mathrm{hr}$ and $\mathrm{BM}$ of $55 \mathrm{~kg}$, the total energy cost of running $42.2 \mathrm{~km}$ is calculated at $\sim 2,200 \mathrm{kcal}(9,210 \mathrm{~kJ})$. Theoretically, this could be provided by CHO (550 g) in the form of supercompensated muscle and liver glycogen stores supplemented by an aggressive approach to consuming $\mathrm{CHO}$ during the race. The total $\mathrm{O}_{2}$ cost of oxidizing $\mathrm{CHO}$ 
alone or fat alone would be $435 \mathrm{~L}$ versus $459 \mathrm{~L}$, respectively (Krogh \& Lindhard, 1920). In our hypothetical athlete with a $\dot{\mathrm{VO}}_{2} \max$ of $80 \mathrm{ml} \cdot \mathrm{kg}^{-1} \cdot \mathrm{min}^{-1}$ (i.e., $4.4 \mathrm{~L} / \mathrm{min}$ ), $\mathrm{VO}_{2}$ during the race would correspond to $3.63 \mathrm{~L} / \mathrm{min}$ (or $83 \% \mathrm{VO}_{2} \max$ ) and $3.83 \mathrm{~L} / \mathrm{min}$ (or $87 \% \mathrm{VO}_{2} \max$ ) using purely $\mathrm{CHO}$ or fat, respectively. However, even more subtle changes in RQ can be meaningful. For example, an athlete with a sustainable $\mathrm{VO}_{2}$ of $3.75 \mathrm{~L} / \mathrm{min}$ and running economy of $180 \mathrm{ml} \cdot \mathrm{kg}^{-1} \cdot \mathrm{min}^{-1}$ would achieve a sustainable marathon running speed of $20.83 \mathrm{~km} / \mathrm{hr}$, with a finishing time of $2: 01: 33$. In this scenario, a $\sim 0.9 \%$ increase in the energy liberated per liter $\mathrm{O}_{2}$ consumed (achieved via a 0.05 unit increment in RQ, e.g., from 0.85 to 0.90 ) could translate into a similar magnitude of increment in running speed (to $21.02 \mathrm{~km} / \mathrm{hr}$ ) and a finishing time of 2:00:27, a $66 \mathrm{~s}$ improvement. For this reason, a key strategy in Nike's 2017 "Breaking 2" marathon attempt, during which a Kenyan athlete Eliud Kipchoge ran a world's best time of 2:00:25, was to encourage $\mathrm{CHO}$ oxidation by supplying $\sim 60-70 \mathrm{~g} / \mathrm{hr} \mathrm{CHO}$ via regular (every $\sim 7 \mathrm{~min}$ ) access to high-concentration drinks (A.M. Jones, personal observations May 6, 2017; Caesar, 2017). Further rigorous study of this concept is needed, but it may become part of the formula for further enhancement of distance running performance.

\section{Conclusions}

Distance athletes should adopt nutrition strategies that address specific physiological and biochemical factors that otherwise limit performance. These include periodized support for specific goals of workouts or phases within the training program and as summarized in Table 2, nutrient choices prior and/or during the race to maintain optimal fuel and fluid status. In-race nutrition is dependent on practicalities, such as the availability of aid stations as well as time and gut considerations of consuming $\mathrm{CHO}$-containing fluids or other sports products. Finally, several performance supplements, particularly caffeine and nitrate, could be considered for likely and potential benefits, respectively.

\section{Acknowledgments}

All authors contributed to the preparation of this manuscript. The authors declare no conflicts of interest in the preparation of this review.

\section{References}

Almond, C.S.D., Shin, A.Y., Fortescue, E.B., Mannix, R.C., Wypij, D., Binstadt, B.A., ... Greenes, D.S. (2005). Hyponatremia among runners in the Boston marathon. New England Journal of Medicine, 352, 1550-1556. PubMed ID: 15829535 doi:10.1056/ NEJMoa043901

Beis, L.Y., Willkomm, L., Ross, R., Bekele, Z., Wolde, B., Fudge, B., \& Pitsiladis, Y.P. (2011). Food and macronutrient intake of elite Ethiopian distance runners. Journal of the International Society of Sports Nutrition, 8, 7. PubMed ID: 21595961 doi:10.1186/15502783-8-7

Beis, L.Y., Wright-Whyte, M., Fudge, B., Noakes, T., \& Pitsiladis, Y.P. (2012). Drinking behaviors of elite male runners during marathon competition. Clinical Journal of Sport Medicine, 22(3), 254-261. PubMed ID: 22450589 doi:10.1097/JSM.0b013e31824a55d7

Black, M.I., Jones, A.M., Blackwell, J.R., Bailey, S.J., Wylie, L.J., McDonagh, S.T., ... Vanhatalo, A. (2017). Muscle metabolic and neuromuscular determinants of fatigue during cycling in different exercise intensity domains. Journal of Applied Physiology, 122(3), 446-459. PubMed ID: 28008101 doi:10.1152/japplphysiol.00942.2016

Bridge, C.A., \& Jones, M.A. (2006). The effect of caffeine ingestion on $8 \mathrm{~km}$ run performance in a field setting. Journal of Sports Science, 24(4), 433-439. doi:10.1080/02640410500231496

Burke, L.M. (2008). Caffeine and sports performance. Applied Physiology Nutrition and Metabolism, 33(6), 1319-1334.

Burke, L.M., Close, G.L., Lundy, B., Mooses, M., Morton, J.P., \& Tenforde, A.S. (2018b). Relative energy deficiency in sport in male athletes: A commentary on its presentation among selected groups of male athletes. International Journal of Sport Nutrition and Exercise Metabolism, 28, 364-374. doi:10.1123/ijsnem.2018-0182

Burke, L.M., \& Hawley, J.A. (2018). Swifter, higher, stronger: What's on the menu? Science, 362(6416), 781-787. PubMed ID: 30442803 doi:10.1126/science.aau2093

Burke, L.M., Hawley, J.A., Jeukendrup, A.E., Morton, J.P., Stellingwerff, T., \& Maughan, R.J. (2018c). Towards a common understanding of diet-exercise strategies to manipulate fuel availability for training and competition preparation for endurance sport. International Journal of Sport Nutrition and Exercise Metabolism, 28, 451-463. doi:10.1123/ ijsnem.2018-0289

Burke, L.M., Hawley, J.A., Wong, S.H., \& Jeukendrup, A.E. (2011). Carbohydrates for training and competition. Journal of Sports Science, 29(Suppl. 1), S17-S27. doi:10.1080/02640414.2011 .585473

Burke, L.M., Lundy, B., Fahrenholtz, I., \& Melin, A. (2018a). Pitfalls of conducting and interpreting estimates of energy availability in freeliving athletes. International Journal of Sport Nutrition and Exercise Metabolism, 28(4), 350-363. doi:10.1123/ijsnem.2018-0142

Burke, L.M., Ross, M.L., Garvican-Lewis, L.A., Welvaert, M., Heikura, I.A., Forbes, S.G., . . Hawley, J.A. (2017). Low carbohydrate, high fat diet impairs exercise economy and negates the performance benefit from intensified training in elite race walkers. Journal of Physiology, 595(9), 2785-2807. PubMed ID: 28012184 doi:10.1113/JP273230

Caesar, E. (2017). The epic untold story of Nike's (almost) perfect marathon. Wired. Retrieved from https://www.wired.com/story/nike-breaking2marathon-eliud-kipchoge/. 26, June 2017.

Casa, D.J., Cheuvront, S.N., Galloway, S.D., \& Shirreffs, S.M. (2019). Fluid needs for training, competition, and recovery in track-and-field athletes. International Journal of Sport Nutrition and Exercise Metabolism, 29. doi:10.1123/ijsnem.2018-0374

Castell, L.M., Nieman, D.C., Bermon, S., \& Peeling, P. (2019). Exerciseinduced illness and inflammation: Can immunonutrition and iron help?International Journal of Sport Nutrition and Exercise Metabolism, 29. doi:10.1123/ijsnem.2018-0288

Christensen, D.L., Van Hall, G., \& Hambraeus, L. (2002). Food and macronutrient intake of male adolescent Kalenjin runners in Kenya. The British Journal of Nutrition, 88(6), 711-717. PubMed ID: 12493093 doi:10.1079/BJN2002728

Cohen, B.S., Nelson, A.G., Prevost, M.C., Thompson, G.D., Marx, B.D., \& Morris, G.S. (1996). Effects of caffeine ingestion on endurance racing in heat and humidity. Journal of Applied Physiology, 73, 358-363.

Conger, S.A., Warren, G.L., Hardy, M.A., \& Millard-Stafford, M.L. (2011). Does caffeine added to carbohydrate provide additional ergogenic benefit for endurance? International Journal of Sport Nutrition and Exercise Metabolism, 21(1), 71-84. PubMed ID: 21411838 doi:10.1123/ijsnem.21.1.71

Conley, D., \& Krahenbuhl, G. (1980). Running economy and distance running performance of highly trained athletes. Medicine \& Science in Sports\& Exercise, 12, 357-360. PubMed ID: 7453514 doi:10. 1249/00005768-198025000-00010 
Costa, R.J.S., Miall, A., Khoo, A., Rauch, C., Snipe, R., Camoes-Costa, V., \& Gibson, P. (2017). Gut-training: The impact of two weeks repetitive gut-challenge during exercise on gastrointestinal status, glucose availability, fuel kinetics, and running performance. Applied Physiology, Nutrition, and Metabolism, 42(5), 547-557. doi:10. 1139/apnm-2016-0453

Cox, G.R., Clark, S.A., Cox, A.J., Halson, S.L., Hargreaves, M., Hawley, J.A., .. Burke, L.M. (2010). Daily training with high carbohydrate availability increases exogenous carbohydrate oxidation during endurance cycling. Journal of Applied Physiology, 109(1), 126134. PubMed ID: 20466803 doi:10.1152/japplphysiol.00950.2009

Coyle, E.F. (1991). Timing and method of increased carbohydrate intake to cope with heavy training, competition and recovery. Journal of Sports Science, 9(Suppl.), 29-52. doi:10.1080/02640419108729865

Coyle, E.F. (2007). Physiological regulation of marathon performance. Sports Medicine, 37(4-5), 306-311. PubMed ID: 18027994 doi:10. 2165/00007256-200737040-00009

Coyle, E.F., Coggan, A.R., Hemmert, M.K., \& Ivy, J.L. (1986). Muscle glycogen utilisation during prolonged strenuous exercise when fed carbohydrate. Journal of Applied Physiology, 61, 165-172. PubMed ID: 3525502 doi:10.1152/jappl.1986.61.1.165

de Castro, T.F., Manoel, F.A., Figueiredo, D.H., Figueiredo, D.H., \& Machado, F.A. (2019). Effect of beetroot juice supplementation on $10-\mathrm{km}$ performance in recreational runners. Applied Physiology, Nutrition, and Metabolism, 44(1), 90-94. doi:10.1139/apnm-2018-0277

Fudge, B.W., Easton, C., Kingsmore, D., Kiplamai, F.K., Onywera, V.O., Westerterp, K.R., \& Pitsiladis, Y.P. (2008). Elite Kenyan endurance runners are hydrated day-to-day with ad libitum fluid intake. Medicine \& Science in Sports \& Exercise, 40(6), 1171-1179. PubMed ID: 18460986 doi:10.1249/MSS.0b013e318169cdda

Fudge, B.W., Westerterp, K.R., Kiplamai, F.K., Onywera, V.O., Boit, M.K., Kayser, B., \& Pitsiladis, Y.P. (2006). Evidence of negative energy balance using doubly labelled water in elite Kenyan endurance runners prior to competition. The British Journal of Nutrition, 95(1), 59-66. PubMed ID: 16441917 doi:10.1079/BJN20051608

Gollnick, P.D., \& Saltin, B (1982). Significance of skeletal muscle oxidative enzyme enhancement with endurance training. Clinical Physiology, 2, 1-12. PubMed ID: 7201906 doi:10.1111/j.1475097X.1982.tb00001.x

Goulet, E.D.B., Aubertin-Leheudre, M., Plante, G.E., \& Dionne, I.J. (2007). A meta-analysis of the effects of glycerol-induced hyperhydration on fluid retention and endurance performance. International Journal of Sport Nutrition and Exercise Metabolism, 17(4), 391-410. PubMed ID: 17962713 doi:10.1123/ijsnem.17.4.391

Hanson, N.J., Martinez, S.C., Byl, E.N., Maceri, R.M., \& Miller, M.G. (2018). Increased rate of heat storage, and no performance benefits, with caffeine ingestion before a 10-km run in hot, humid conditions. International Journal of Sports Physiology and Performance, 14(2), 196-202. doi:10.1123/ijspp.2018-0263

Hawley, J.A., \& Leckey, J.J. (2015). Carbohydrate dependence during prolonged, intense endurance exercise. Sports Medicine, 45(Suppl. 1), S5-S12. doi:10.1007/s40279-015-0400-1

Heikura, I.A., Stellingwerff, T., \& Burke, L.M. (2018). Self-reported periodization of nutrition in elite female and male runners and race walkers. Frontiers in Physiology, 9, 1732. PubMed ID: 30559680 doi:10.3389/fphys.2018.0173

Hughson, R.L., Orok, C.J., \& Staudt, L.E. (1984). A high velocity treadmill running test to assess endurance running potential. International Journal of Sports Medicine, 5(1), 23-25. PubMed ID: 6698679 doi:10.1055/s-2008-1025875

Hurley, B., Hagberg, J., Allen, W., Seals, D.R., Young, J.C., Cuddihy, R.W., \& Holloszy, J.O. (1984). Effect of training on blood lactate levels during sub-maximal exercise. Journal of Applied Physiology, 56, 1260-1264. PubMed ID: 6725086 doi:10.1152/jappl.1984. 56.5.1260

Hutchinson, A. (2013, November 8). Haile Gebrselassie's world record marathon fueling plan. Runner's World. Retrieved from https://www.runnersworld.com/nutrition-weight-loss/a20812496/hailegebrselassies-world-record-marathon-fueling-plan

Hyman, M. (1970). Diet and athletics. British Medical Journal, 4(5726), 52. PubMed ID: 5470443 doi:10.1136/bmj.4.5726.52-b

Ivy, J.L., Withers, R.T., Van Handel, P.J., Elger, D.H., \& Costill, D.L. (1980). Muscle respiratory capacity and fibre type as determinants of the lactate threshold. Journal of Applied Physiology, 48, 523-527. PubMed ID: 7372524 doi:10.1152/jappl.1980.48.3.523

Jay, O., \& Morris, N.B. (2018). Does cold water or ice slurry ingestion during exercise elicit a net body cooling effect in the heat? Sports Medicine, 48(Suppl. 1), 17-29. PubMed ID: 29368184 doi:10.1007/ s40279-017-0842-8

Jentjens, R.L.P.G., Wagenmakers, A.J.M., \& Jeukendrup, A.E. (2002). Heat stress increases muscle glycogen use but reduces the oxidation of ingested carbohydrates during exercise. Journal of Applied Physiology, 92, 1562-1572. PubMed ID: 11896023 doi:10.1152/ japplphysiol.00482.2001

Jeukendrup, A. (2014). A step towards personalized sports nutrition: Carbohydrate intake during exercise. Sports Medicine, 44(Suppl 1), 25-33. doi:10.1007/s40279-014-0148-z

Jeukendrup, A.E. (2017a). Periodized nutrition for athletes. Sports Medicine, 47(Suppl. 1), 51-63. doi:10.1007/s40279-017-0694-2

Jeukendrup, A.E. (2017b). Training the gut for athletes. Sports Medicine, 47(Suppl. 1), 101-110. doi:10.1007/s40279-017-0690-6

Jeukendrup, A.E., \& Chambers, E.S. (2010). Oral carbohydrate sensing and exercise performance. Current Opinions in Clinical Nutrition and Metabolic Care, 13(4), 447-451. doi:10.1097/MCO.0b013e32833 9de83

Jones, A.M., Thompson, C., Wylie, L.J., \& Vanhatalo, A. (2018). Dietary nitrate and physical performance. Annual Review of Nutrition, 38, 303-328. PubMed ID: 30130468 doi:10.1146/annurev-nutr-082117051622

Jones, A.M., \& Vanhatalo, A. (2017). The 'critical power' concept: Applications to sports performance with a focus on intermittent high-intensity exercise. Sports Medicine, 47(Suppl. 1), 65-78. PubMed ID: 28332113 doi:10.1007/s40279-017-0688-0

Jonvik, K.L., Nyakayiru, J., van Loon, L.J., \& Verdijk, L.B. (2015). Can elite athletes benefit from dietary nitrate supplementation? Journal of Applied Physiology, 119(6), 759-761. PubMed ID: 25997946 doi:10. 1152/japplphysiol.00232.2015

Joyner, M.J., \& Coyle, E.F. (2008). Endurance exercise performance: The physiology of champions. Journal of Physiology, 586(1), 35-44. PubMed ID: 17901124 doi:10.1113/jphysiol.2007.143834

Karlsson, J., \& Saltin, B. (1971). Diet, muscle glycogen, and endurance performance. Journal of Applied Physiology, 31, 203-206. PubMed ID: 5558241 doi:10.1152/jappl.1971.31.2.203

Kent, G.L., Dawson, B., Cox, G.R., Abbiss, C.R., Smith, K.J., Croft, K.D., ... Peeling, P. (2018). Effect of dietary nitrate supplementation on thermoregulatory and cardiovascular responses to submaximal cycling in the heat. European Journal of Applied Physiology, 118(3), 657-668. PubMed ID: 29356948 doi:10.1007/s00421-018$3809-\mathrm{z}$

Krogh, A., \& Lindhard, J. (1920). The relative value of fat and carbohydrate as sources of muscular energy: With appendices on the correlation between standard metabolism and the respiratory quotient during rest and work. Biochemistry Journal, 14(3-4), 290-363. doi:10.1042/ bj0140290 
Lane, S.C., Areta, J.L., Bird, S.R., Coffey, V.G., Burke, L.M., Desbrow, B., ... Hawley, J.A. (2013). Caffeine ingestion and cycling power output in a low or normal muscle glycogen state. Medicine \& Science in Sports \& Exercise, 45(8), 1577-1584. PubMed ID: 23439421 doi:10.1249/MSS.0b01

Larsen, H.B., \& Sheel, A.W. (2015). The Kenyan runners. Scandinavian Journal of Medicine and Science in Sports, 25(Suppl. 4), 110-118. doi:10.1111/sms.12573

Leverve, X., Batandier, C., \& Fontaine, E. (2007). Choosing the right substrate. Novartis Foundation Symposium, 280, 108-121; discussion 121-107, 160-104. PubMed ID: 17380791

Londeree, B.R. (1986). The use of laboratory test results with long distance runners. Sports Medicine, 3(3), 201-213. PubMed ID: 3520749 doi:10.2165/00007256-198603030-00004

Marquet, L.A., Brisswalter, J., Louis, J., Tiollier, E., Burke, L.M., Hawley, J.A., \& Hausswirth, C. (2016). Enhanced endurance performance by periodization of carbohydrate intake: "Sleep low" strategy. Medicine \& Science in Sports \& Exercise, 48(4), 663-672. PubMed ID: 26741119 doi:10.1249/MSS.0000000000000823

Maughan, R.J., Burke, L.M., Dvorak, J., Larson-Meyer, D.E., Peeling, P., Phillips, S.M., .. . Engebretsen, L. (2018). IOC consensus statement: Dietary supplements and the high-performance athlete. International Journal of Sport Nutrition and Exercise Metabolism, 28(2), 104-125. PubMed ID: 29589768 doi:10.1123/ijsnem.2018-0020

McMahon, N.F., Leveritt, M.D., \& Pavey, T.G. (2017). The effect of dietary nitrate supplementation on endurance exercise performance in healthy adults: A systematic review and meta-analysis. Sports Medicine, 47(4), 735-756. PubMed ID: 27600147 doi:10.1007/s40279-01

Melin, A.K., Heikura, I.A., Tenforde, A., \& Mountjoy, M. (2019). Energy availability in athletics: Health, performance, and physique. International Journal of Sport Nutrition and Exercise Metabolism, 29. doi:10 .1123/ijsnem.2018-0201

Montain, S.J., \& Coyle, E.F. (1992). Influence of graded dehydration on hyperthermia and cardiovascular drift during exercise. Journal of Applied Physiology, 73(4), 1340-1350. PubMed ID: 1447078 doi:10. 1152/jappl.1992.73.4.1340

Mooses, M., \& Hackney, A.C. (2017). Anthropometrics and body composition in East African runners: Potential impact on performance. International Journal of Sports Physiology and Performance, 12, 422-430. PubMed ID: 27631418 doi:10.1123/ijspp.2016-0408

Morgan, D., \& Craib, M. (1992). Physiological aspects of running economy. Medicine \& Science in Sports \& Exercise, 24, 456-461. PubMed ID: 1560743

Mountjoy, M., Sundgot-Borgen, J., Burke, L., Ackerman, K.E., Blauwet, C., Constantini, N., ... Budgett, R. (2018). International olympic committee (IOC) consensus statement on relative energy deficiency in sport (RED-S): 2018 update. International Journal of Sport Nutrition and Exercise Metabolism, 28(4), 316-331. PubMed ID: 29771168

Onywera, V.O., Kiplamai, F.K., Boit, M.K., \& Pitsiladis, Y.P. (2004). Food and macronutrient intake of elite Kenyan distance runners. International Journal of Sport Nutrition and Exercise Metabolism, 14(6), 709-719. PubMed ID: 15657475 doi:10.1123/ijsnem.14.6.709

Peeling, P., Castell, L.M., Derave, W., de Hon, O., \& Burke, L.M. (2019). Sports foods and dietary supplements for optimal function and performance enhancement in track-and-field athletes. International Journal of Sport Nutrition and Exercise Metabolism, 29. doi:10.1123/ ijsnem.2018-0271

Poole, D.C., Burnley, M., Vanhatalo, A., Rossiter, H.B., \& Jones, A.M. (2016). Critical power: An important fatigue threshold in exercise physiology. Medicine \& Science in Sports \& Exercise, 48(11), 2320 2334. PubMed ID: 27031742 doi:10.1249/MSS.0000000000000939
Poole, D.C., Ward, S.A., Gardner, G.W., \& Whipp, B.J. (1988). Metabolic and respiratory profile of the upper limit for prolonged exercise in man. Ergonomics, 31(9), 1265-1279. PubMed ID: 3191904 doi:10. 1080/00140138808966766

Potgieter, S., Wright, H.H., \& Smith, C. (2018). Caffeine improves triathlon performance: A field study in males and females. International Journal of Sport Nutrition and Exercise Metabolism, 28(3), 228-237. PubMed ID: 29345161 doi:10.1123/ijsnem.2017-0165

Racinais, S., Alonso, J.M., Coutts, A.J., Flouris, A.D., Girard, O., Gonzalez-Alonso, J., ... Periard, J.D. (2015). Consensus recommendations on training and competing in the heat. British Journal of Sports Medicine, 49(18), 1164-1173. PubMed ID: 26069301 doi:10. 1136/bjsports-2015-094915

Reale, R., Slater, G., \& Burke, LM. (2017). Acute-weight-loss strategies for combat sports and applications to Olympic success. International Journal of Sports Physiology and Performance, 12, 142-151. PubMed ID: 27347784 doi:10.1123/ijspp.2016-0211

Rehrer, N.J., Beckers, E.J., Brouns, F., Ten Hoor, F., \& Saris, W.H.M. (1990). Effects of dehydration on gastric emptying and gastrointestinal distress while running. Medicine \& Science in Sports \& Exercise, 22, 790-795. PubMed ID: 2287256 doi:10.1249/00005768199012000-00010

Roberts, P.A., Fox, J., Peirce, N., Jones, S.W., Casey, A., \& Greenhaff, P.L. (2016). Creatine ingestion augments dietary carbohydrate mediated muscle glycogen supercompensation during the initial $24 \mathrm{~h}$ of recovery following prolonged exhaustive exercise in humans. Amino Acids, 48(8), 1831-1842. PubMed ID: 27193231 doi:10.1007/ s00726-016-2252-x

Ross, M., Abbiss, C., Laursen, P., Martin, D., \& Burke, L. (2013). Precooling methods and their effects on athletic performance: A systematic review and practical applications. Sports Medicine, 43(3), 207-225. PubMed ID: 23329610 doi:10.1007/s40279-012-0014-9

Sahlin, K. (1992). Metabolic factors in fatigue. Sports Medicine, 13(2), 99-107. PubMed ID: 1561513 doi:10.2165/00007256-19921302000005

Saltin, B., \& Astrand, P.O. (1967). Maximal oxygen uptake in athletes. Journal of Applied Physiology, 23, 353-358. PubMed ID: 6047957 doi:10.1152/jappl.1967.23.3.353

Saunders, P.U., Pyne, D.B., Telford, R.D., \& Hawley, J.A. (2004). Factors affecting running economy in trained distance runners. Sports Medicine, 34(7), 465-485. PubMed ID: 15233599 doi:10.2165/00007256200434070-00005

Sawka, M.N., Cheuvront, S.N., \& Kenefick, R.W. (2015). Hypohydration and human performance: Impact of environment and physiological mechanisms. Sports Medicine, 45(Suppl. 1), S51-S60. doi:10.1007/ s40279-015-0395-7

Shannon, O.M., Barlow, M.J., Duckworth, L., Williams, E., Wort, G., Woods, D., ... O'Hara, J.P. (2017). Dietary nitrate supplementation enhances short but not longer duration running time-trial performance. European Journal of Applied Physiology, 117(4), 775-785. PubMed ID: 28251402 doi:10.1007/s00421-017-3580-6

Smith, J.W., Zachwieja, J.J., Peronnet, F., Passe, D.H., Massicotte, D., Lavoie, C., \& Pascoe, D.D. (2010). Fuel selection and cycling endurance performance with ingestion of [13C]glucose: Evidence for a carbohydrate dose response. Journal of Applied Physiology, 108(6), 1520-1529. PubMed ID: 20299609 doi:10.1152/japplphysiol. 91394.2008

Snipe, R.M.J., Khoo, A., Kitic, C.M., Gibson, P.R., \& Costa, R.J.S. (2017). Carbohydrate and protein intake during exertional heat stress ameliorates intestinal epithelial injury and small intestine permeability. Applied Physiology, Nutrition, and Metabolism, 42(12), 1283-1292. doi:10.1139/apnm-2017-036 
Southward, K., Rutherfurd-Markwick, K.J., \& Ali, A. (2018a). The effect of acute caffeine ingestion on endurance performance: A systematic review and meta-analysis. Sports Medicine, 48(8), 1913-1928. doi:10. 1007/s40279-018-0939-8

Southward, K., Rutherfurd-Markwick, K., Badenhorst, C., \& Ali, A. (2018b). The role of genetics in moderating the inter-individual differences in the ergogenicity of caffeine. Nutrients, 10(10), pii: E1352. doi:10.3390/nu10101352

Spriet, L.L. (2014). Exercise and sport performance with low doses of caffeine. Sports Medicine, 44(Suppl. 2), 175-184. doi:10.1007/ s40279-014-0257-8

Stellingwerff, T. (2012). Case study: Nutrition and training periodization in three elite marathon runners. International Journal of Sport Nutrition and Exercise Metabolism, 22(5), 392-400. doi:10.1123/ ijsnem.22.5.392

Stellingwerff, T. (2018). Case study: Body composition periodization in an olympic-level female middle-distance runner over a 9-year career. International Journal of Sport Nutrition and Exercise Metabolism, 28(4), 428-433. PubMed ID: 29140157 doi:10.1123/ijsnem.20170312

Stellingwerff, T., Morton, J.P., \& Burke, L.M. (2019). A framework for periodized nutrition for athletics. International Journal of Sport Nutrition and Exercise Metabolism, 1-29. doi:10.1123/ijsnem.2018-0305

Stellingwerff, T., \& Cox, G.R. (2014). Systematic review: Carbohydrate supplementation on exercise performance or capacity of varying durations. Applied Physiology, Nutrition, and Metabolism, 39, 998-1011. doi:10.1139/apnm-2014-002

Stevens, C.J. \& Best, R. (2017). Menthol: A fresh ergogenic aid for athletic performance. Sports Medicine, 47(6), 1035-1042. PubMed ID: 27858306 doi:10.1007/s40279-016-0652-4

Tan, R., Wylie, L.J., Thompson, C., Blackwell, J.R., Bailey, S.J., Vanhatalo, A., \& Jones, A.M. (2018). Beetroot juice ingestion during prolonged moderate-intensity exercise attenuates progressive rise in $\mathrm{O}_{2}$ uptake. Journal of Applied Physiology, 124(5), 1254-1263. PubMed ID: 29357494 doi:10.1152/japplphysiol. 01006.2017

Thomas, D.T., Erdman, K.A., \& Burke, L.M. (2016). American College of Sports Medicine joint position statement. Nutrition and Athletic Performance. Medicine \& Science in Sports \& Exercise, 48(3), 543-568. PubMed ID: 26891166 doi:10.1249/MSS.0000000000000852

Tomcik, K.A., Camera, D.M., Bone, J.L., Ross, M.L., Jeacocke, N.A., Tachtsis, B., .. Burke, L.M. (2018). Effects of creatine and carbohydrate loading on cycling time trial performance. Medicine \& Science in Sports \& Exercise, 50(1), 141-150. PubMed ID: 28806275 doi:10.1249/MSS.0000000000001401

Vandenbogaerde, T.J., \& Hopkins, W.G. (2011). Effects of acute carbohydrate supplementation on endurance performance: A meta-analysis. Sports Medicine, 41(9), 773-792. doi:10.2165/11590520-00000000000000 PubMed ID: 21846165

Vanhauwaert, E., Matthys, C., Verdonck, L., \& De Preter, V. (2015). Lowresidue and low-fiber diets in gastrointestinal disease management. Advances in Nutrition, 6(6), 820-827. doi:10.3945/an.115.009688 PubMed ID: 26567203

van Nieuwenhoven, M.A., Brouns, F., \& Kovacs, E.M. (2005). The effect of two sports drinks and water on GI complaints and performance during an 18-km run. International Journal of Sports Medicine, 26(4), 281-285. PubMed ID: 15795812 doi:10.1055/s-2004-820931

van Rosendal, S.P., \& Coombes, J.S. (2013). Glycerol use in hyperhydration and rehydration: Scientific update. Medicine and Sport Science, 59, 104-112. doi:10.1159/000341959

Williams, K., \& Cavanagh, P. (1987). Relationship between distance running mechanics, running economy, and performance. Journal of Applied Physiology, 63, 1236-1245. PubMed ID: 3654469 doi:10.1152/jappl.1987.63.3.1236 